
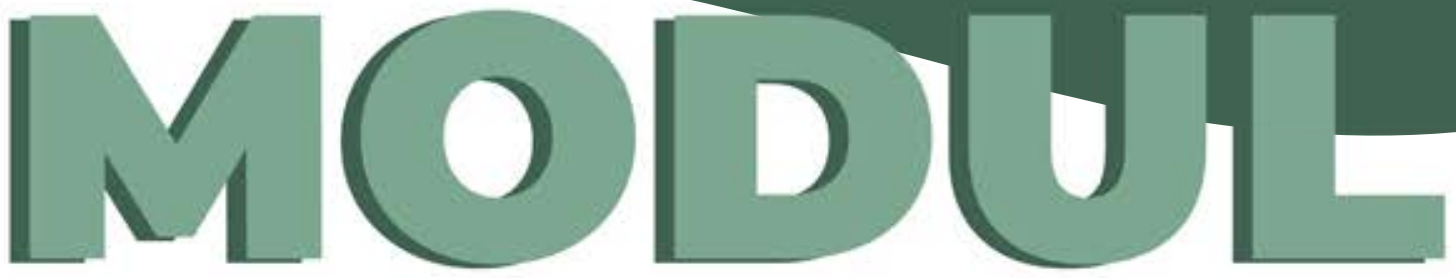

PENDIDIKAN KESEHATAN DAN PEMENUHAN GIZI SEIMBANG PADA IBU MENYUSUI DAN BADUTA

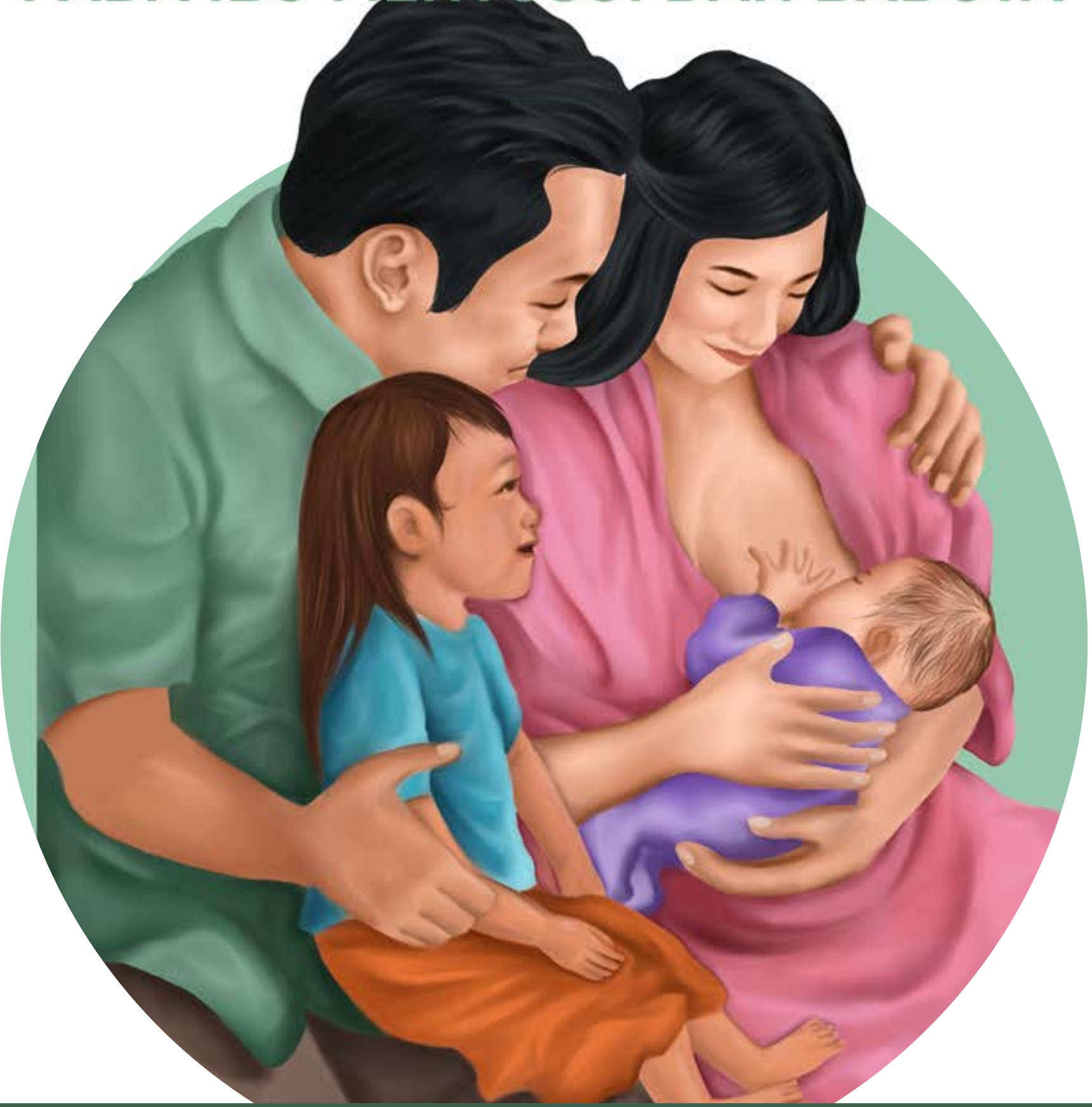

Departemen Kesehatan Masyarakat dan Kedokteran Pencegahan

Fakultas Kedokteran Universitas Udayana 2021 


\title{
MODUL \\ PENDIDIKAN KESEHATAN DAN PEMENUHAN GIZI SEIMBANG PADA IBU MENYUSUI DAN BADUTA
}

\author{
Penulis: \\ Dr. Kadek Tresna Adhi, S.KM, M.Kes \\ Dinar Saurmauli Lubis, S.KM, MPH, PhD \\ Dr. dr I Gede Ngurah Indraguna Pinatih, M.Sc.Akp, Sp.GK \\ I Gusti Agung Agus Mahendra, SKM. MPH
}

Departemen Kesehatan Masyarakat dan Kedokteran Pencegahan Fakultas Kedokteran Universitas Udayana

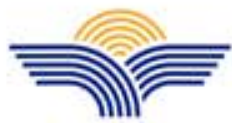

PENERBIT

PANUDUH ATMA WARAS

Jl. ByPass Ngurah Rai Nomor: 888 xx, Denpasar, Bali - Indonesia

(0361) 6209990

$(+62) 82236180725$ 


\title{
MODUL \\ PENDIDIKAN KESEHATAN DAN PEMENUHAN GIZI SEIMBANG \\ PADA IBU MENYUSUI DAN BADUTA
}

\author{
Penulis : \\ Dr. Kadek Tresna Adhi, S.KM, M.Kes \\ Dinar Saurmauli Lubis, S.KM, MPH, PhD \\ Dr. dr I Gede Ngurah Indraguna Pinatih, M.Sc.Akp, Sp.GK \\ I Gusti Agung Agus Mahendra, SKM. MPH
}

ISBN (PDF) : 978-623-97473-6-7

Copyright @ Juli 2021

Hak Cipta dilindungi oleh Undang-Undang. Pertama kali diterbitkan di Indonesia dalam Bahasa Indonesia oleh PANUDUH ATMA WARAS. Penggunaan material dalam karya ini diatur dalam Lisensi Publik Creative Commons 4.0 Atribusi-NonKomersial-TanpaTurunan (CC-BY-ND). Pengguna dapat mengutip konten dalam karya ini dengan memberi kredit yang sepantasnya kepada penulis asli karya ini. Dilarang menggunakan karya ini untuk kepentingan komersial dalam bentuk apapun. Dilarang mengubah dan menyebarluaskan isi karya ini dalam bentuk apa pun tanpa izin tertulis dari penulis.

\section{PENERBIT}

PANUDUH ATMA WARAS

Jl. ByPass Ngurah Rai Nomor: 888 xx, Denpasar, Bali - Indonesia

(0361) 6209990; (+62)82236180725

info@baswarapress.com

panuduhatmawaras@gmail.com 


\section{UCAPAN TERIMA KASIH}

Selama menyusun modul ini tim penulis telah banyak mendapat bantuan dan dukungan dari berbagai pihak baik secara langsung maupun tidak langsung. Untuk itu, dengan segala kerendahan hati, tim penulis bermaksud untuk menyampaikan ucapan terima kasih yang sebesar-besarnya kepada semua pihak yang turut membantu, khususnya:

1. Dekan Fakultas Kedokteran Universitas Udayana beserta jajarannya.

2. Tim East Bali Proverty Project (EBPP).

3. Tim validator modul. 


\section{KATA PENGANTAR}

Permasalahan gizi di Desa Ban, Kabupaten Karangasem, Provinsi Bali sudah berlangsung lama khususnya pada ibu menyusui dan baduta serta telah dilakukan berbagai upaya intervensi untuk mengatasi masalah gizi di desa ini. Mengingat luasnya dampak yang diakibatkan oleh permasalahan gizi pada ibu menyusui dan baduta, maka perlu sebuah upaya inovatif yang dapat dijadikan strategi pendekatan untuk percepatan perbaikan status gizi pada kelompok-kelompok tersebut.

Berdasarkan hal tersebut pendekatan keluarga sebagai basis dukungan perubahan perilaku yang dikembangkan dengan tujuan untuk meningkatan pengetahuan, menumbuhkan sikap positif dan mewujudkan perilaku yang mendukung pada pemenuhan gizi seimbang pada ibu menyusui dan baduta, sehingga dapat berdampak pada perbaikan dan peningkatan status gizi. Modul Pendidikan Kesehatan dan Pemenuhan Gizi Seimbang pada Ibu Menyusui dan Baduta, dibuat untuk menjadi pegangan petugas lapangan/fasilitator dalam menyampaikan materi yang telah direncanakan pada waktu melatih dan menemani keluarga ibu baduta.

Kami sangat berterima kasih terhadap semua pihak yang telah membantu dalam penyusunan modul ini serta pihak yang mengapresiasi dan menggunakan modul ini sebagai acuan dalam pelaksanaan intervensi gizi keluarga. Kami menyadari bahwa masih terdapat berbagai kekurangan dalam modul ini, sehingga kritik dan saran pengguna modul sangat diharapkan. Harapan kami, modul ini bermanfaat bagi petugas lapangan/fasilitator dalam rangka meningkatkan keterampilan dan kepercayaan diri saat melaksanakan dan memberikan materi pada kelompok sasaran di lapangan.

Tim Penulis 


\section{DAFTAR}

ISI

SAMPUL

PENULIS

LEMBAR ISBN

UCAPAN TERIMAKASIH

KATA PENGANTAR

DAFTAR ISI

DAFTAR TABEL

DAFTAR GAMBAR

Pengantar Modul

Latar Belakang

Tujuan Penyusunan Modul

Sasaran Kegiatan Penyusunan Modul

Silabus Modul Intervensi Pendekatan Keluarga Ibu Baduta

Materi Modul

Sesi pertemuan 1. Gizi Seimbang bagi Ibu Menyusui

Mengapa keluarga perlu memahami gizi seimbang selama

ibu menyusui?

Daftar pertanyaan dan jawaban

Sesi pertemuan 2. ASI Eksklusif dan MPASI Optimal

Mengapa penting keluarga mendukung Ibu untuk memberikan

ASI eksklusif?

Mengapa penting keluarga memberikan baduta MPASI Optimal?

Daftar pertanyaan dan jawaban

Sesi pertemuan 3. Pemantauan Pertumbuhan di Posyandu

Apa peran keluarga dalam memantau pertumbuhan anak baduta

di Posyandu?

Daftar pertanyaan dan jawaban

Referensi

Protokol Kesehatan selama implementasi intervensi

pendekatan keluarga pada keluarga ibu Baduta

LAMPIRAN 


\section{DAFTAR TABEL}

Tabel 1. Rekomendasi pemberian MPASI pada Baduta usia 6-24 bulan 


\section{DAFTAR GAMBAR}

Gambar 1. Tumpeng gizi seimbang untuk ibu menyusui

Gambar 2. Pesan khusus gizi seimbang untuk ibu menyusui 19

Gambar 3. Pesan penting ASI Eksklusif

Gambar 4. Manfaat pemberian ASI Eksklusif

Gambar 5. Pesan penting MPASI optimal

Gambar 6. Dampak pemberian makanan dan minuman tambahan sebelum baduta berusia 6 bulan

Gambar 7. Pentingnya melanjutkan pemberian ASI pada Baduta setelah usia 6 bulan sampai 2 tahun atau lebih

Gambar 8. Pemberian makan aktif/responsif untuk Baduta 6-24 bulan

Gambar 9. Pemantauan pertumbuhan Baduta di Posyandu 


\section{PENGANTAR MODUL}

\section{Latar Belakang}

Tantangan utama yang dihadapi oleh Indonesia salah satunya adalah membangun sumber daya manusia yang berkualitas, sehat, cerdas, dan produktif. Pembangunan kesehatan berdasarkan Rencana Pembangunan Jangka Menengah Nasional (RPJMN) periode tahun 2020-2024 salah satunya memprioritaskan peningkatan status kesehatan ibu dan anak serta peningkatan status gizi di masyarakat (Kemenkes, 2020).

Salah satu permasalahan gizi yang sedang dihadapi oleh Indonesia saat ini adalah permasalahan kekurangan gizi pada anak usia 0-23 bulan atau anak usia bawah dua tahun (baduta) yang telah menjadi agenda dan prioritas nasional. Tercatat pada Riskesdas tahun 2018 bahwa secara nasional prevalensi gizi buruk dan gizi kurang pada anak baduta mencapai 3,8\% dan $11,4 \%$ secara berurutan. Sementara itu prevalensi anak baduta yang pendek (stunting) mencapai 29,9\% (Kemenkes, 2019). Berdasarkan hal tersebut prevalensi anak baduta yang stunting masih di atas target RPJMN tahun 2019 yaitu sebesar 28\% (Kemenkes, 2020).

Di Provinsi Bali, prevalensi stunting pada baduta mengalami fluktuasi dari tahun 2007 sampai 2013 dan terakhir pada Riset Kesehatan Dasar (Riskesdas) tahun 2018 mencapai 24,7\% (Kemenkes, 2019b, 2019a). Kabupaten Karangasem tercatat menjadi salah satu kabupaten dengan kasus stunting tertinggi di Provinsi Bali, yaitu sebesar 35,1\% (Kemenkes, 2019b). Selain permasalahan stunting, berdasarkan penelitian pendahulan yang dilakukan oleh Departemen Kesehatan Masyarakat dan Kedokteran Pencegahan (KMPK), Fakultas Kedokteran, Universitas Udayana yang bekerja sama dengan East Bali Proverty Project (EBPP) pada tahun 2019 di Desa Ban, Karangasem Bali menemukan bahwa kasus gizi kurang pada anak baduta juga cukup tinggi mencapai 3,18 \% dan ibu menyusui dengan dengan gizi kurang mencapai 7,64\% (Lubis et al., 2020).

Berbagai upaya telah dilakukan untuk mengatasi permasalahan gizi di Desa Ban, Namun permasalahan gizi sudah menjadi permasalahan klasik di Desa Ban dan secara umum di Kabupaten Karangasem. Untuk mengatasi permasalahan ini tim peneliti dari Departemen KMKP bekerja sama dengan Yayasan Ekoturin me-

nawarkan konsep pendekatan keluarga sebagai salah satu upaya untuk mengatasi permasalahan gizi buruk dan stunting pada anak baduta termasuk gizi buruk pada ibu Baduta di Desa Ban. Berbagai studi menunjukkan bahwa keluarga sangat berperan dalam menentukan pola asuh dan konsumsi ibu menyusui dan anak baduta, yang dapat berpengaruh pada status gizi dan kesejahteraannya (Walton et al., 2019; Martin et al., 2020).

masyarakat, tingkat pendidikan dan kesehatan dengan melakukan pendekatan yang berbasis posyandu maupun secara individu pada bayi yang menderita gizi buruk. Namun dirasakan bahwa upaya tersebut belum menunjukkan hasil yang cukup maksimal untuk dapat meningkatkan status gizi masyarakat pada kelompok rentan gizi seperti Ibu hamil, ibu baduta, baduta dan remaja. 


\section{PENGANTAR \\ MODUL}

Untuk mendukung kegiatan kegiatan yang telah dilakukan selama ini, Yayasan Ekoturin bekerjasama dengan tim peneliti dari Departemen KMKP untuk mengetahui efektifitas dari konsep pendekatan keluarga sebagai salah satu upaya untuk mengatasi permasalahan gizi di Desa Ban. Berbagai data empiris menunjukkan bahwa keluarga sangat berperan dalam menentukan pola asuh dan konsumsi makanan utama pada anak remaja (Utter et al., 2019).Upaya yang dilakukan adalah dengan mengembangkan suatu model edukasi gizi yang menyasar seluruh anggota, namun khusus untuk pendekatan pada remaja, dikembangkan dengan menggunakan pendekatan peers atau teman sebaya. Modul ini disusun sebagai bagian dari intervensi dimaksud dan bertujuan sebagai bahan acuan bagi fasilitator dalam memberikan edukasi gizi pada remaja. Adapun yang menjadi fasilitator adalah staff EBBPP yang telah terlatih untuk memfasilitasi kegiatan edukasi pada masyarakat dan telah memahami permasalahan yang dihadapi oleh masyarakat Desa Ban.

\section{Tujuan Penyusunan Modul}

Modul ini disusun dengan tujuan utama sebagai buku pedoman bagi fasilitator dalam menyampaikan pendidikan kesehatan dan pemenuhan gizi seimbang pada ibu menyusui dan anak baduta di Desa Ban Karangasem, Bali. Adapun yang menjadi tujuan khusus dari penyusuan modul ini adalah sebagai berikut:

1. Meningkatkan pengetahuan keluarga ibu Baduta tentang konsep gizi seim bang untuk ibu menyusui dan Baduta serta pentingnya pemantauan pertumbuhan Baduta di Posyandu.

2. Membentuk sikap positif dan dukungan dari keluarga ibu Baduta terutama suami/ayah terhadap konsep gizi seimbang bagi ibu menyusui dan Baduta serta serta pentingnya pemantauan pertumbuhan Baduta di Posyandu.

3. Membentuk perilaku pemenuhan gizi seimbang untuk ibu menyusui dan Baduta serta perilaku pemantauan pertumbuhan Baduta di Posyandu.

\section{Sasaran Penyusunan Modul}

Adapun sasaran dari modul ini adalah keluarga ibu baduta. Yang dimaksud sebagai keluarga ibu Baduta adalah keluarga yang memiliki anak yang berusia 0-23 bulan yang tidak mengalami catat bawaan, penyakit berat ataupun kelainan metabolisme tertentu. Anggota keluarga ibu baduta yang dapat dijadikan sasaran dalam intervensi pemberian materi modul ini oleh fasilitator adalah ibu dan atau ayah dari baduta termasuk anggota keluarga lainnya yang terlibat dalam menentukan asuhan dan pola makan di keluarga tersebut. Pemberian intervensi atau penyampaian materi pada keluarga ibu baduta dilakukan dengan metode diskusi partisipatif dengan menggunakan pendekatan komunikasi dua arah. Fasilitator yang memberikan intervensi pendidikan kesehatan dan pemenuhan gizi seimbang pada keluarga ibu baduta adalah petugas kesehatan lapangan dari EBPP yang telah dilatih dan dinyatakan memiliki kompetensi untuk melaksanakan intervensi. 


\section{Silabus Modul Intervensi Pendekatan Keluarga Ibu Baduta}

Sasaran : Keluarga ibu Baduta

Pemberi materi : Fasilitator yang telah terlatih

Total durasi : 90 menit

Metode evaluasi : Pre dan posttest survei

Materi
Pembelajaran

Sesi pertemuan 1:

Gizi Seimbang

bagi Ibu Menyusui

\section{Uraian Materi dan Permainan}

Mengapa

keluarga perlu

memahami gizi

seimbang selama

ibu menyusui?

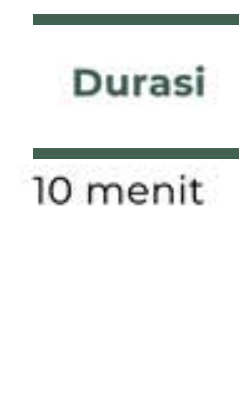

Permainan: Porsi makan ibu menyusui

$\begin{array}{ll} & \text { Metode } \\ & \text { Door to } \\ \text { door } \\ \checkmark \text { Diskusi } \\ \text { interaktif } \\ \text { dengan } \\ \text { metode } \\ \text { komuni- } \\ \text { kasi dua } \\ \text { arah }\end{array}$

20 menit

Permainan

\section{Media}

Gambar tumpeng gizi seimbang untuk ibu menyusui dan gambar pesan khusus gizi seimbang untuk ibu menyusui yang terdapat pada Modul Pendidikan Kesehatan dan Pemenuhan Gizi Seimbang pada Ibu Menyusui dan Baduta

Gambar foto makanan
Keluaran yang diharapkan

$\checkmark$ Pemahaman keluarga mengenai pemenuhan gizi seimbang untuk ibu menyusui

$\checkmark$ Sikap positif dan dukungan keluarga dalam pemenuhan gizi seimbang untuk ibu menyusui

$\checkmark$ Perilaku pemenuhan gizi seimbang untuk ibu menyusui yang dilakukan oleh keluarga ibu baduta

Pemahaman keluarga
mengenai sumber makanan
apa saja yang patut
dikonsumsi oleh ibu menyusui
dalam satu kali porsi makan
sehari-hari
$\checkmark$ Perilaku penyediaan dan
konsumsi sumber makanan
yang patut dikonsumsi oleh
ibu menyusui dalam satu kali
porsi makan sehari-hari




Materi
Pembelajaran

Sesi pertemuan 2:

ASI Eksklusif dan

MPASI Optimal

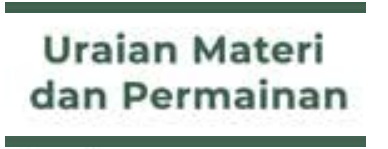

\section{Review}

pertemuan 1

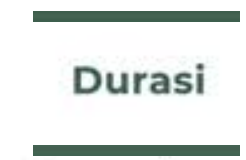

5 menit

\section{Mengapa}

penting keluarga

mendukung Ibu

untuk memberi-

kan ASI

eksklusif?

10 menit$$
\text { (1) }
$$

\section{Metode}

\section{Door to \\ door}

$\checkmark$ Diskusi

interaktif

dengan

metode

komunika-

si dua arah

$\checkmark$ Door to
door
$\checkmark$ Diskusi
interaktif
dengan
metode
komuni-
kasi dua
arah

Mengapa

penting keluarga

memberikan

anak baduta

MPASI optimal?

10 menit

\section{Keluaran yang diharapkan}

$\checkmark$ Kemampuan keluarga ibu baduta dalam mengingat dan menjelaskan kembali pesan-pesan kunci materi pada pertemuan 1

$\checkmark$ Gambar mengenai Pesan penting ASI eksklusif dan manfaat pemberian ASI eksklusif pada Baduta usia $<6$ bulan yang terdapat pada Modul Pendidikan Kesehatan dan Pemenuhan Gizi Seimbang pada Ibu Menyusui dan Baduta $\checkmark$ Door to door

$\checkmark$ Diskusi interaktif dengan metode komunikasi dua arah $\checkmark$ Pemahaman keluarga mengenai pentingnya pem berian ASI eksklusif pada anak baduta usia $<6$ bulan

$\checkmark$ Sikap positif dan dukungan keluarga dalam pemberian ASI eksklusif pada anak baduta usia $<6$ bulan

$\checkmark$ Perilaku pemberian ASI eksklusif pada Baduta usia $<6$ bulan yang didukung oleh keluarga ibu baduta

$\checkmark$ Pemahaman keluarga mengenai pentingnya pem berian MPASI yang optimal pada anak baduta usia 6 bulan keatas

$\checkmark$ Sikap positif dan dukungan keluarga dalam pemberian MPASI yang optimal pada baduta usia 6 bulan keatas

$\checkmark$ Perilaku pemberian MPASI yang optimal pada anak baduta usia 6 bulan keatas yang didukung oleh keluarga ibu baduta

\section{Baduta}

$\checkmark$ Gambar pesan penting MPASI opti mal; gambar dampak pemberian makanan pada bayi sebelum usia 6 bulan; Gambar pentingnya me neruskan pemberian ASI setelah usia 6 bulan sampai 2 tahun atau lebih; dan Gambar re komendasi MPASI 
Materi

Pembelajaran

\section{Uraian Materi dan Permainan}

Permainan:

ASI saja cukup

\section{Review \\ pertemuan 2}

Sesi pertemuan 3

Pemantauan Pertumbuhan di Posyandu

Apa peran

keluarga dalam

\section{Durasi}

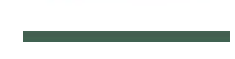

Metode
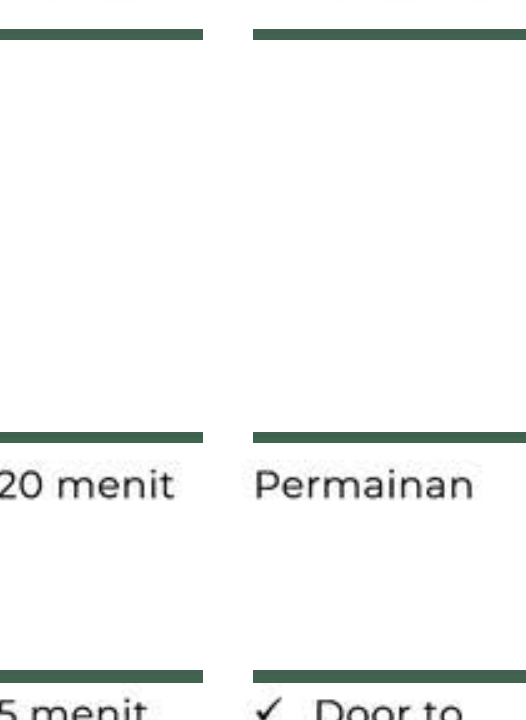

\section{$\checkmark$}

\section{door}

Door to

$\checkmark$ Diskusi

interaktif

dengan

metode

komunika-

si dua arah

memantau per-

tumbuhan anak

baduta di

Posyandu?

10 menit untuk Baduta usia

6-24 bulan yang ter dapat pada Modul

Pendidikan Keseha

tan dan Pemenuhan

Gizi Seimbang pada

Ibu Menyusui dan

Baduta

EMO DEMO: Demo

Rumpi Sehat 01 ASI saja

cukup, oleh GAIN dan

Kementerian Kesehatan

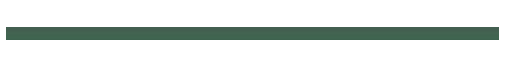

$\begin{array}{ll} & \text { Door to } \\ \text { door } \\ \checkmark \text { Diskusi in } \\ \text { teraktif } \\ \text { dengan } \\ \text { metode } \\ \text { komuni- } \\ \text { kasi dua } \\ \text { arah }\end{array}$

Gambar mengenai pemantauan per tumbuhan Baduta di Posyandu yang terdapat pada Modul Pendidikan Keseha tan dan Pemenuhan Gizi Seimbang pada Ibu Menyusui dan Baduta $\checkmark$ Pemahaman keluarga Baduta mengenai pentingnya memberikan ASI secara eksklusif pada bayi usia $<6$ bulan

$\checkmark$ Kemampuan keluarga ibu baduta dalam mengingat dan menjelaskan kembali pesan-pesan kunci materi pada pertemuan 2

$\checkmark$ Pemahaman keluarga ibu Baduta mengenai pentingnya pemantauan pertumbuhan Baduta di Posyandu

$\checkmark$ Sikap positif dan dukungan keluarga dalam pemantauan pertumbuhan Baduta di Posyandu secara rutin

$\checkmark$ Perilaku pemantauan pertum buhan Baduta di Posyandu yang didukung dan didampingi oleh keluarga ibu Baduta 


\section{MATERI MODUL}

\section{Sesi pertemuan 1. Gizi Seimbang bagi Ibu Menyusui}

\section{Tujuan pembelajaran untuk keluarga ibu menyusui:}

$\checkmark$ Meningkatkan pemahaman keluarga ibu Baduta mengenai pemenuhan gizi seimbang untuk ibu menyusui

$\checkmark$ Menumbuhkan sikap positif dan dukungan keluarga dalam pemenuhan gizi seimbang untuk ibu menyusui

$\checkmark$ Mewujudkan perilaku pemenuhan gizi seimbang untuk ibu menyusui yang dilakukan oleh keluarga ibu Baduta

\section{Metode penyampaian:}

1. Diskusi interaktif dengan metode komunikasi dua arah

2. Permainan porsi makan ibu menyusui

Alokasi waktu: 30 menit

\section{Alat dan media:}

Selama diskusi, fasilitator dapat menampilkan alat dan media penyampaian informasi sebagai berikut:

1. Gambar 1. Tumpeng Gizi Seimbang untuk ibu menyusui

2. Gambar 2. Piring satu porsi makan untuk ibu menyusui

Untuk permainan porsi makan ibu menyusui, fasilitator mempersiapkan:

1. Gambar foto makanan sumber zat tenaga (karbohidrat), seperti: beras/nasi, umbi-umbian dan jagung.

2. Gambar foto makanan sumber zat pembangun (protein hewani dan nabati), seperti: daging, ikan, ayam, ati ayam, telur, tahu, tempe dan kacangkacangan.

3. Gambar foto makanan sumber zat pengatur (vitamin dan mineral), seperti: sayuran dan buah-buahan.

4. Gambar foto makanan yang berisikan 1 piring/porsi makanan untuk 1 kali makan bagi ibu menyusui.

\section{Panduan proses untuk diskusi:}

1. Fasilitator datang ke rumah sesuai janji dengan keluarga ibu Baduta yang telah disepakai sebelumnya

2. Fasilitator memberikan salam, memperkenalkan diri dan menjelaskan tujuan kegiatan

3. Fasilitator menjelaskan mekanisme diskusi yang akan berlangsung, seperti bebas untuk berpendapat dan bertanya, aktif dan fokus selama berdiskusi serta bersedia meluangkan waktu selama 30 menit untuk berdiskusi secara kondusif.

4. Fasilitator memulai diskusi dengan brainstorming mengenai jenis makanan apa saja yang selama ini dikonsumsi oleh ibu menyusui 
5. Fasilitator melanjutkan diskusi dengan memperlihatkan dan menjelaskan Gambar 1 mengenai tumpeng gizi seimbang.

6. Fasilitator tetap terbuka untuk menanggapi apabila ada pertanyaan selama diskusi

\section{Panduan permainan porsi makan ibu menyusui}

Tujuan permainan: untuk meningkatkan pengetahuan keluarga ibu baduta mengenai porsi makanan yang tepat dan memenuhi gizi seimbang untuk ibu menyusui.

\section{Langkah-langkah:}

1. Berikan pertanyaan terbuka mengenai makanan ada saja yang ada disekitar dan terjangkau untuk dikonsumsi oleh ibu menyusui.

Contoh:

"Makanan apa saja yang wajib dikonsumsi oleh ibu menyusui?" "Ada yang bisa menyebutkannya?"

2. Kemudian tunjukkan beberapa gambar foto makanan. Minta keluarga ibu baduta untuk mendiskusikan foto makanan mana yang merupakan makanan pokok/sumber tenaga, makanan sumber zat pembangun dan pengatur. Kemudian diskusikan mengenai kemungkinan keluarga untuk mendapatkan/membeli makanan-makanan tersebut dan menyediakannya untuk ibu menyusui. Tanyakan mengapa bisa atau tidak bisa menyediakan. Apabila tidak bisa menyediakan, diskusikan bersama makanan alternatif yang lebih mudah diperoleh dan terjangkau.

3. Berikan pertanyaan pancingan mengenai porsi makan ibu menyusui dalam 1 kali makan.

Contoh:

"Bapak/Ibu ada yang tahu sebapa banyak/porsi makan makanan pokok untuk ibu menyusui?" "Bagaimana dengan porsi protein nabati dan hewani serta sayuran dan buahnya?"

4. Tunjukkan foto gambar piring yang berisikan 1 porsi makanan untuk ibu menyusui dalam 1 kali makan. Tanyakan bagaimana pendapat keluarga. Diskusinya kemungkinan pemenuhan porsi makanan ibu menyusui tersebut setiap harinya.

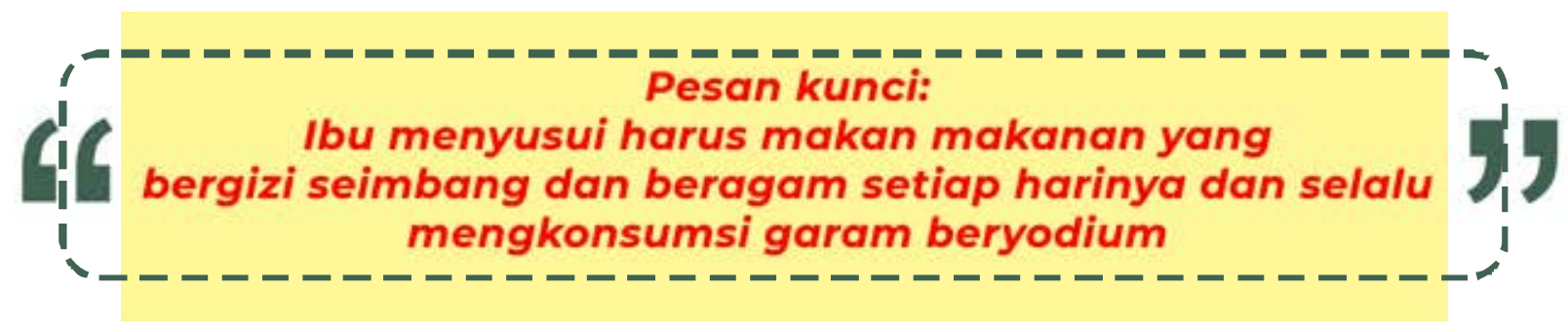




\section{URAIAN MATERI}

Mengapa keluarga perlu memahami gizi seimbang

selama ibu menyusui? 


\section{Mengapa keluarga perlu memahami gizi seimbang selama ibu menyusui?}

$\checkmark$ Asupan gizi pada masa bayi usia $<6$ bulan dipenuhi oleh ibunya melalui Air Susu Ibu (ASI).

$\checkmark$ Ibu menyusui harus memperhatikan setiap makanannya, setiap makanan yang dikonsumsinya akan mempengaruhi kualitas dan kuantititas ASI.

$\checkmark$ Periode menyusui (bayi berusia 0-23 bulan) merupakan masa yang sangat peting bagi bayi dan ibu, sama pentingnya dengan masa kehamilan.

$\checkmark$ Pada periode menyusui ini hubungan emosional antara bayi dan ibunya akan terbentuk dengan baik, sehingga masa menyusui ini sangat baik bagi perkembangan mental dan psikis bayi, dan pada masa ini bayi akan dapat merasakan besarnya kasih sayang dan kehangatan yang diberikan oleh ibu kepadanya.

$\checkmark$ Besarnya kasih sayang/emosi ibu sangat dipengaruhi oleh perhatian/kepedulian keluarga khususnya suami/ayah

$\checkmark$ Gizi Seimbang untuk ibu menyusui harus memenuhi kebutuhan bagi dirinya dan untuk pertumbuhan serta perkembangan bayi. Dengan demikian maka kebutuhan zat gizi ibu menyusui lebih banyak dari kebutuhan zat gizi ibu yang tidak menyusui.

$\checkmark$ Konsumsi pangannya tetap harus beraneka ragam dan seimbang dalam jumlah dan proporsinya. Selama menyusui, ibu harus menambah jumlah dan jenis makanan yang dikonsumsi yaitu untuk mencukupi kebutuhan ibu sendiri dan kebutuhan untuk memproduksi ASI.

$\checkmark$ Apabila makanan yang dikonsumsi ibu tidak mengandung zat gizi yang mencukupi kebutuhan saat menyusui, maka kekurangannya akan diambil dari persediaan zat gizi yang berada didalam tubuh ibu agar kebutuhan bayi tetap terpenuhi. 


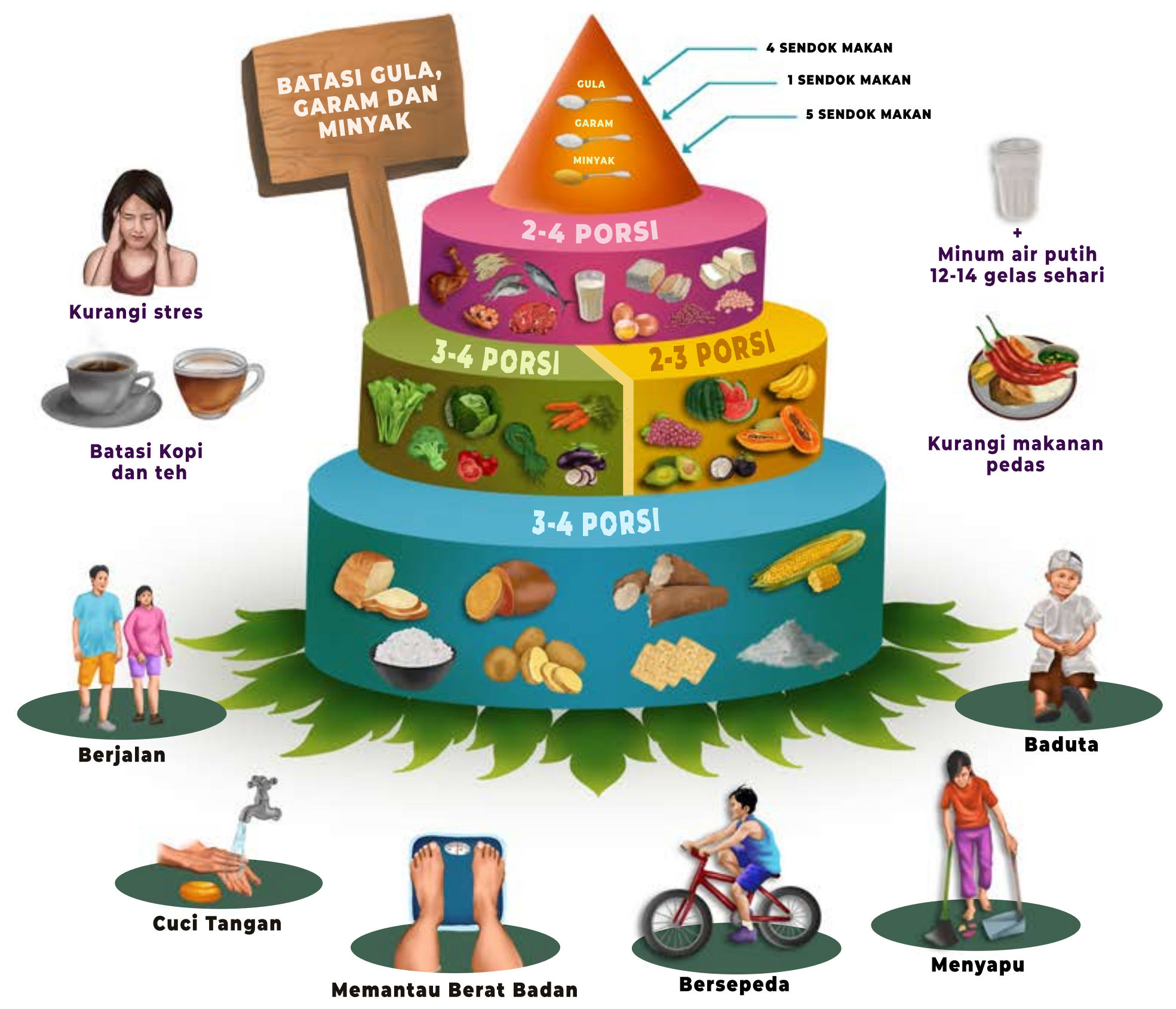

Gambar 1. Tumpeng gizi seimbang untuk ibu menyusui 
1. Biasakan mengonsumsi aneka ragam makanan setiap hari yang terdiri dari

- Sumber karbohidrat: beras, roti, ubi, mie, jagung, dan lainnya

- Sumber protein: daging, ikan, telur, tahu, tempe dan kacangkacangan

- Sumber vitamin dan mineral: aneka sayuran dan buah-buahan

2. Membiasakan hidup bersih, contohnya rajin mencuci tangan, menjaga kebersihan makanan, kebersihan diri dan lingkungan

3. Melakukan aktivitas fisik sesuai kondisi tubuh ibu

4. Minum air putih sekitar 12-14 gelas selama sehari,

5. Membatasi konsumsi gula, garam dan minyak dalam makanan dan minuman

6. Membatasi konsumsi kopi dan teh, maksimal 2 cangkir dalam sehari

7. Mengurangi makanan yang pedas dan menghindari makanan yang sangat pedas

8. Mengurangi stress karena berpengaruh pada kelancaran produksi ASI

9. Menggunakan garam beriodium dalam makanannya 


\section{Daftar Pertanyaan dan Jawaban}

\section{Pertanyaan}

Apakah benar ibu tidak boleh makan ikan agar ASI tidak menjadi amis?

Apakah benar ibu menyusui yang makan makanan pedas dapat menyebabkan bayi mencret?

Apakah benar saat bayi sakit, ibulah yang sebaiknya minum obat?

\section{Jawaban}

Ikan adalah salah satu makanan terbaik selama menyusui. Kandungan lemak omega 3 pada ikan, terutama ikan laut sangat penting untuk perkembangan otak bayi, penguatan dinding sel, mencegah risiko jantung koroner dan mengontrol kolesterol dalam darah.

Ibu menyusui sebaiknya menghindari makan pedas yang berlebihan karena dapat menyebabkan diare pada ibu yang dapat memicu dehidrasi. Dehidrasi selain berbahaya bagi ibu, juga dapat mengganggu proses pemberian ASI pada bayi

Apabila bayi sakit harus lebih sering diberikan ASI. Namun apabila ibu yang sakit, maka harus memberitahukan pada dokter bahwa ibu sedang dalam masa menyusui. 


\section{MATERI MODUL}

\section{Sesi pertemuan 2. ASI Eksklusif dan MPASI Optimal}

\section{Tujuan pembelajaran untuk keluarga ibu Baduta:}

$\checkmark$ Meningkatkan pemahaman keluarga ibu Baduta terutama ayah mengenai pentingnya pemberian ASI eksklusif pada Baduta usia $<6$ bulan dan pemberian MPASI yang optimal pada Baduta usia 6 bulan keatas.

$\checkmark$ Sikap positif dan dukungan keluarga/ayah dalam pemberian ASI eksklusif pada Baduta usia $<6$ bulan dan pemberian MPASI yang optimal pada Baduta usia 6 bulan keatas.

$\checkmark$ Perilaku pemberian ASI eksklusif pada Baduta usia $<6$ bulan dan pemberian MPASI yang optimal pada Baduta usia 6 bulan keatas, yang didukung oleh keluarga ibu Baduta

\section{Metode penyampaian:}

1. Diskusi interaktif dengan metode komunikasi dua arah

2. Permainan ASI saja cukup

Alokasi waktu: 45 menit

\section{Alat dan media:}

Selama diskusi, fasilitator dapat menampilkan alat dan media penyampaian informasi sebagai berikut:

1. Gambar 3. Pesan penting ASI eksklusif

2. Gambar 4. Manfaat pemberian ASI Eksklusif

3. Gambar 5. Pesan penting MPASI optimal

4. Gambar 6. Dampak pemberian makanan tambahan sebelum baduta berusia 6 bulan

5. Gambar 7. Pentingnya melanjutkan pemberian ASI pada Baduta setelah usia 6 bulan sampai 2 tahun atau lebih

6. Gambar 8. Rekomendasi pemberian MPASI pada Baduta usia 6-24 bulan

7. Gambar 9. Pemberian makan aktif/responsif untuk Baduta 6-24 bulan.

Untuk permainan ASI saja cukup, fasilitator mempersiapkan:

1. Susu cair

2. Minyak goreng

3. Kartu perut bayi

4. 4 gelas ukur

5. 2 gelas plastik air

6. 8 benda ukuran kecil ke besar (manik, kemiri, kelereng, bola bekel, kluwek, bola pingpong, telur mainan dan bola tenis)

\section{Panduan proses untuk diskusi:}

1. Fasilitator datang ke rumah sesuai janji dengan keluarga ibu baduta yang telah disepakai sebelumnya. Pastikan seluruh keluarga yang terlibat terutama ayah (harus) hadir dalam pertemuan. 
2. Fasilitator menjelaskan mekanisme diskusi yang akan berlangsung, seperti bebas untuk berpendapat dan bertanya, aktif dan fokus selama berdiskusi serta bersedia meluangkan waktu selama 45 menit untuk berdiskusi secara kondusif.

3. Fasilitator memulai diskusi dengan brainstorming mengenai pemberian ASI dan MPASI untuk Baduta yang ada di keluarga, jikalau ayah pasif fasilitator tetap meminta pendapat ayah.

4. Fasilitator mulai menjelaskan mengenai ASI eksklusif dan manfaatnya menggunakan Gambar 3 dan 4.

5. Fasilitator melanjutkan menjelaskan mengeai pemberian MPASI yang optimal saat Baduta sudah berusia 6 bulan, menggunakan Gambar 5-8.

6. Fasilitator melanjutkan diskusi dengan membahas studi kasus mengenai baduta yang susah makan. Fasilitator dapat memulai diskusi dengan menggunakan pertanyaan pancingan.

Contoh:

"Bapak/lbu apakah anak Anda selama ini makan dengan lahap? atau susah makan? Menurut Bapak/lbu apa yang harus dilakukan apabila anak susah makan?". Fasilitator dapat menggunakan Gambar 9 untuk membantu menjelaskan cara-cara mengatasi anak yang susah makan.

7. Fasilitator tetap terbuka untuk menanggapi apabila ada pertanyaan selama diskusi.

\section{Panduan permainan ASI saja cukup:}

Tujuan permainan:

$\checkmark$ Ibu belajar bahwa sampai usia 6 bulan, ukuran perut bayi sangat kecil dan cukup hanya minum ASI.

$\checkmark$ Ibu belajar bahwa ASI yang keluar akan sesuai dengan kebutuhan anaknya. Semakin sering ASI dihisap, maka produksi ASI akan semakin banyak.

Langkah:

1. Hal yang harus dilakukan sebelum peserta datang: Isi 4 gelas ukur susu sesuai dengan volumenya (lihat kartu perut bayi). Sembunyikan gelas ini terlebih dahulu.

2. Tampilkan 8 benda ukuran kecil-besar yang telah disiapkan. Minta peserta diskusi menebak ukuran perut bayi. Gunakan kartu perut bayi sebagai alat bantu (halaman dengan logo).

Contoh:

"Menurut Ibu/bapak, berapa besar perut bayi yang baru lahir pada hari pertama? 3 hari? 1 minggu? 1 bulan? Berapa ukurannya?"

3. Tanyakan peserta yang lain untuk memastikan seluruh ibu berpartisipasi. Contoh:

"Apakah Bapak/ibu setuju? Bagaimana dengan yang lain?"

4. Jelaskan jawaban yang benar dengan membuka kartu perut bayi. Kemudian letakkan gelas ukur yang telah diisi susu di samping benda yang benar. Contoh:

"Bagaimana menurut Ibu/bapak? Apakah perut bayi lebih kecil atau lebih besar dari yang Ibu/bapak pikirkan?"

5. Diskusikan permainan.

Contoh:

"Setelah kita bermain tadi, apa yang Ibu/Bapak pikirkan?

Apakah Ibu/bapak terkejut? Bagaimana menurut peserta yang lain?"

"Apakah Ibu/bapak pikir ASI ibu cukup? Saat bayi menangis, apakah selalu karena lapar? Apakah ada alasan lain?" 
6. Gunakan kembali susu cair diatas dan siapkan:

1 gelas ukur berisi $150 \mathrm{ml}$ susu cair

1 gelas ukur berisi $80 \mathrm{ml}$ susu cair

1 gelas ukur berisi $70 \mathrm{ml}$ minyak

Pilih dua anggota keluarga/peserta diskusi untuk menjadi sukarelawan 1 dan 2. Ambil 2 gelas kosong yang diibaratkan sebagai perut bayi dari sukarelawan 1 dan sukarelawan 2.

Contoh:

"Sukarelawan 1 dan 2 memiliki anak yang berumur 1 bulan. Disini ada 2 gelas kosong yang kita ibaratkan sebagai perut bayi sukarelawan 1 dan 2 .

Sukarelawan 1 memberikan ASI saja pada bayinya, sedangkan sukarelawan 2 memberikan ASI ditambah susu formula. Kita ibaratkan susu ini sebagai ASI dan minyak sebagai susu formula."

7. Tunjukkan gelas sukarelawan 1 yang akan diisi susu cair pada saat cerita mengenai pemberian ASI.

Contoh:

"Saat anaknya menangis, sukarelawan 1 menyusui anaknya (tuangkan susu secukupnya- sambil mengibaratkan bayi menghisap ASI)." "3 jam kemudian, sukarewalan 1 kembali menyusui anaknya (tuangkan susu - bayi menghisap ASI) - ulangi hingga susu dalam gelas ukur habis ( 5 x penuangan)."

8. Tunjukkan gelas sukarelawan 2 , dan tuangkan susu cair sembari bercerita mengenai pemberian ASI dan tuangkan minyak pada saat sukarelawan 2 memberikan susu formula.

Contoh:

"Pagi hari, sukarelawan 2 menyusui anaknya (tuangkan susu secukupnya bayi menghisap ASI). Pada siang hari, sukarelawan 2 memberikan susu formula

(tuangkan minyak - ulangi bergantian hingga susu dan minyak habis)."

9. Tunjukkan gelas kedua sukarelawan. Kedua gelas berisi sekitar $150 \mathrm{ml}$. Tunjukkan bahwa produksi ASI sukarelawan 1 lebih banyak dari sukarelawan 2. Gelas sukarelawan 1 menunjukkan susu cair yang diibaratkan ASI sebanyak $150 \mathrm{ml}$. Sedangkan pada gelas sukarelawan 2 terdapat minyak yang diibaratkan susu formula sebanyak $70 \mathrm{ml}$.

Contoh:

"Berapa ASI yang diproduksi Ibu Sri?" "Berapa ASI yang diproduksi Ibu Rumpi?"

10. Diskusikan permainan.

Contoh:

"Jika kita lihat gelas kedua sukarelawan, bayi siapa yang lebih sering minum ASI? sukarelawan siapa yang produksi ASInya lebih banyak?"

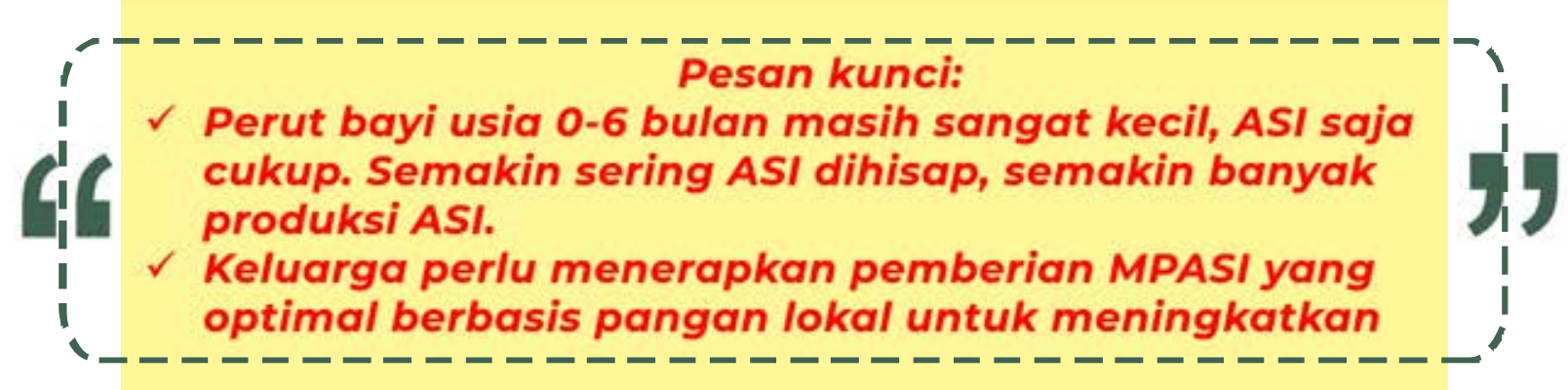




\section{URAIAN MATERI}

Mengapa penting keluarga mendukung lbu untuk memberikan ASI eksklusif? 


\section{Mengapa penting keluarga mendukung Ibu untuk memberikan ASI eksklusif?}

Sejak bayi baru lahir sampai usia 6 bulan, ASI (Air Susu Ibu) sangat penting untuk diberikan pada bayi. Usia bayi 0-6 bulan hanya diberikan ASI tanpa makanan atau minuman tambahan atau disebut dengan istilah ASI Eksklusif.

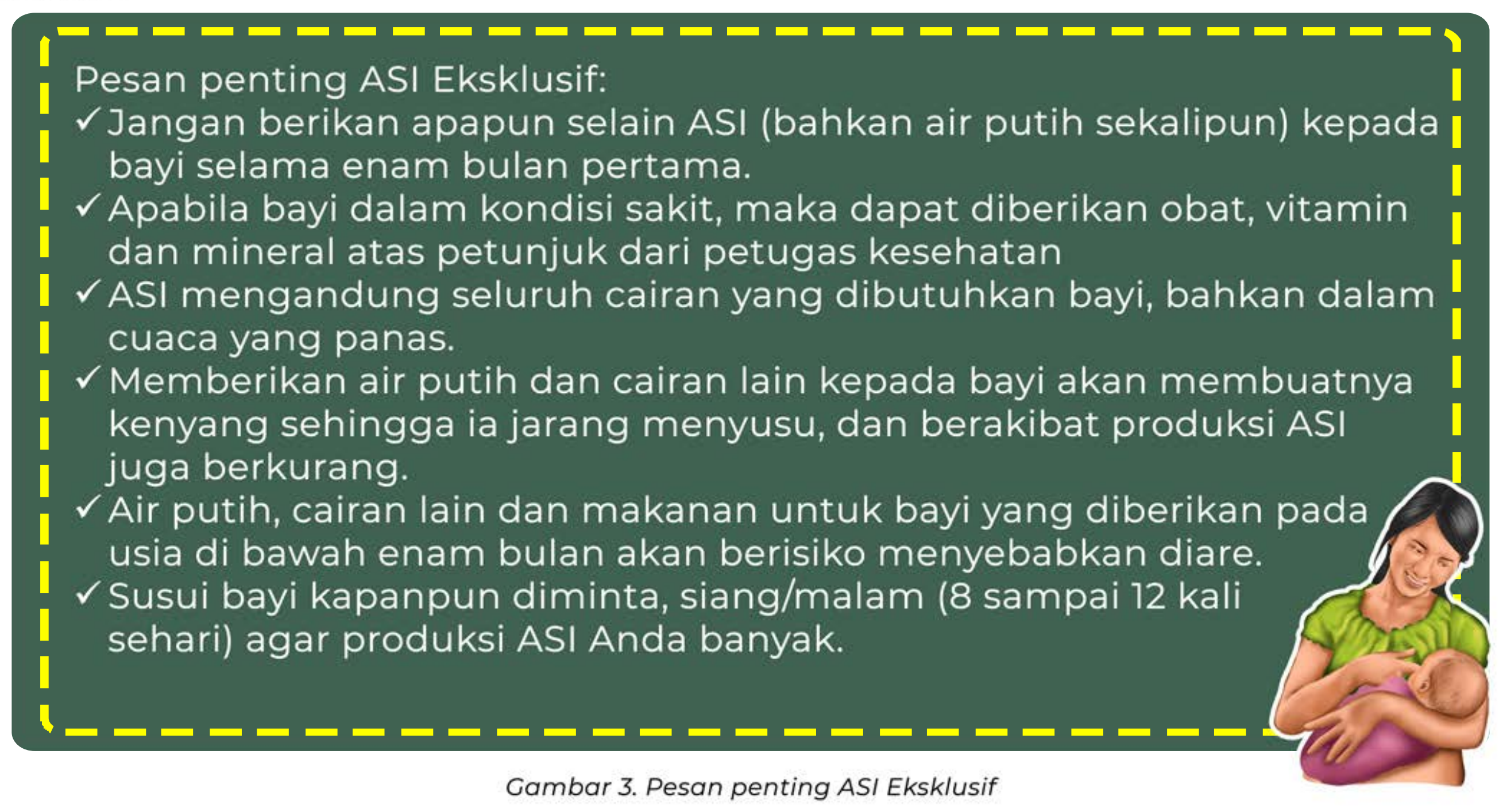


ASI mempunyai banyak manfaat bagi ibu dan bayi diantaranya:

- Sehat, praktis, dan tidak memerlukan biaya yang bayak

- Meningkatkan daya tahan tubuh alami pada bayi

- Mencegah terjadinya perdarahan pada ibu nifas (pasca melahirkan)

- Menurunkan risiko kanker payudara

- Menjalin kasih sayang antara ibu dengan bayi

Gambar 4. Manfaat pemberian ASI Eksklusif 


\section{Mengapa penting keluarga memberikan baduta MPASI Optimal?}

MPASI merupakan singkatan dari Makanan Pendamping Air Susu Ibu. Seperti namanya, MPASI merupakan makanan pendamping bukan pengganti ASI. Pemberian MPASI dimulai sejak bayi telah memasuki usia 6 bulan. Selama pemberian MPASI bayi tetap diberikan ASI sampai bayi berusia 2 tahun.

Hal yang perlu diperhatikan dalam pemberian MPASI yaitu:

- MPASI yang baik harus mengandung energi, protein, serta zat gizi mikro seperti zat besi, zink, kalsium, iodium, vitamin A, dan folat (detail pada Gambar 8 dan Lampiran 1)

- Tidak mengandung bumbu yang tajam, tidak menggunakan gula, garam, penyedap rasa, pewarna, dan pengawet.

- Mudah ditelan dan disukai oleh anak

- Tersedia secara lokal dan harga yang terjangkau

- Pemberian MPASI bayi disesuaikan dengan usia bayi.

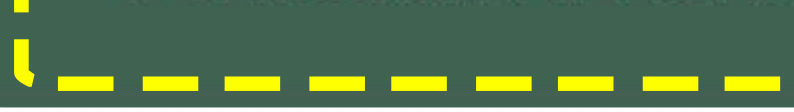

Gambar 5. Pesan penting MPASI optimal 
Pemberian makanan atau minuman tambahan sebelum usia bayi memasuki 6 bulan menyebabkan beberapa dampak yang merugikan pada I bayi diantaranya:

- Bayi menjadi lebih rentan terserang penyakit

- Sistem pencernaan bayi belum siap

- Berisiko untuk mengalami alergi makanan

- Obesitas pada bayi

- Produksi ASI berkurang

- Bayi tidak mendapat nutrisi yang optimal

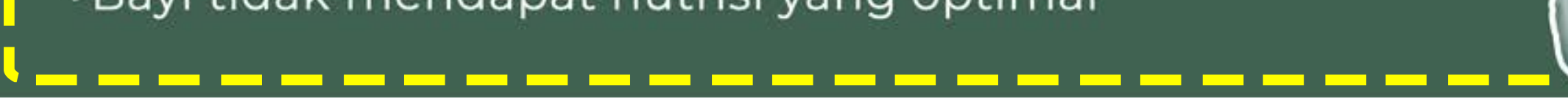

Gambar 6. Dampak pemberian makanan dan minuman tambahan sebelum baduta berus 
Pentingnya melanjutkan pemberian ASI setelah usia bayi 6 bulan:

$\checkmark$ Dari usia O sampai 6 bulan ASI memberikan seluruh kebutuhan energi anak.

$\checkmark$ Dari usia 6 sampai 9 bulan ASI terus memberikan dua pertiga kebutuhan energi anak; sepertiga lagi dari kebutuhan energi itu harus diberikan dari makanan pendamping (MP ASI).

$\checkmark$ Dari usia 9 sampai 12 bulan ASI terus memberikan sekitar setengah kebutuhan energi anak; setengah lagi dari kebutuhan energi itu harus diberikan dari makanan pendamping (MP ASI).

$\checkmark$ Dari usia 12 sampai 24 bulan ASI terus memberikan sekitar sepertiga kebutuhan energi anak, sisanya harus diberikan dari makanan pendamping.

Gambar 7. Pentingnya melanjutkan pemberian ASI pada Baduta setelah usia 6 bulan sampai 2 tahun atau lebih 
Tabel 1. Rekomendasi pemberian MPASI pada Baduta usia 6-24 bulan

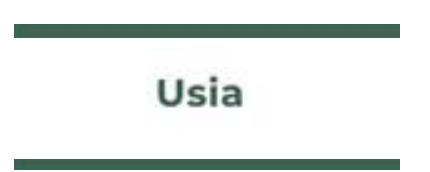

Mulai berikan makanan tambahan ketika anak berusia 6 bulan

Dari usia 6 sampai

9 Bulan

Frekuensi
(perhari)

2 sampai 3 kali makan ditambah ASI

2-3 kali makan ditambah ASI 1-2 kali makanan selingan*

Dari usia 9 sampai 12 bulan

3-4 kali makan Ditambah ASI 1-2 kali makanan selingan*

3 sampai 4 kali

Dari usia 12-24

bulan makan Ditambah ASI

1-2 kali makanan selingan*

Catatan: Jika anak kurang dari 24

bulan tidak diberi ASI*
Tambahkan 1-2 kali makan ekstra

1-2 kali makanan selingan* bisa diberikan

Jumlah setiap
kali makan

Mulai dengan 2 sampai 3 sendok makan. Mulai dengan pengenalan rasa dan secara perlahan tingkatkan jumlahnya

2 sampai 3 sendok makan penuh setiap kali makan Tingkatkan secara perlahan sampai $1 / 2$ (setengah) mangkuk berukuran $250 \mathrm{ml}$

$1 / 2$ (Setengah) sampai $3 / 4$ (tiga perempat) mangkuk berukuran $250 \mathrm{ml}$

\section{Tekstur (kekentalan/ konsistensi)}

\section{Bubur kental}

Bubur kental/makanan keluarga yang dilumatkan

Makanan keluarga yang dicincang/ dicacah. Makanan dengan potongan kecil yang dapat dipegang Makanan yang diiris- iris

$3 / 4$ (tiga perempat) sampai 1 (satu) mangkuk ukuran 250 $\mathrm{ml}$

Sama dengan di atas menurut kelompok Usia
Makanan yang diiris- iris makanan keluarga

Sama dengan di atas menurut kelompok usia

\section{Variasi}

ASI (bayi disusui sesering yang diinginkan)

Makanan hewani (ayam, ikan, dII)

$+$

Makanan Pokok (bubur, Makanan lokal lainnya)

Kacang merah dll +

Buah-buah/sayuran (jeruk, daun labu, bayam, dlI)

Tabur gizi/ Taburia (tidak wajib)

Sama dengan di atas, dengan penambahan 1 sampai 2 gelas susu per hari + 2 sampai 3 kali cairan tambahan terutama didaerah dengan udara panas

\section{Catatan:}

*Makanan selingan atau snack untuk baduta tidak berupa cemilan sembarangan atau memberikan susu formula 


\section{Studi kasus: Baduta yang susah makan}

\section{"Bagaimana kalau Baduta usia 6-23 bulan susah makan?"}

Definisi: Pemberian makan secara aktif/responsif adalah bersikap perhatian dan responsif terhadap tanda-tanda yang disampaikan anak bahwa ia siap untuk makan; berikan dorongan secara aktif kepada anak untuk makan, tapi jangan paksa dia.

Pentingnya pemberian makan secara aktif: Bila anak makan sendiri, mungkin dia tidak akan kenyang. la gampang terganggu. Oleh sebab itu, anak perlu bantuan. Bila anak tidak mendapatkan makanan yang cukup, ia akan menjadi kurang gizi.

$\checkmark$ Biarkan anak makan dari piringnya sendiri (pengasuh akan tahu seberapa banyak anak makan).

$\checkmark$ Duduk bersama anak, bersikap sabar dan berikan dorongan agar ia mau makan.

$\checkmark$ Berikan makanan yang bisa diambil dan dipegang anak; anak-anak sering kali ingin makan sendiri. Berikan dia dorongan untuk melakukan itu,tapi pastikan bahwa makanan itu memang masuk ke mulut nya.

$\checkmark$ Ibu/ayah/pengasuh bisa menggunakan tangannya (setelah dicuci) untuk menyuapi anak.

$\checkmark$ Beri anak makan begitu ia memperlihatkan tanda bahwa ia lapar.

$\checkmark$ Jika anak menolak untuk makan, terus berikan dorongan; cobalah untuk memangku anak waktu memberinya makan.

$\checkmark$ Ajak anak bermain coba untuk menjadikan makan sebagai pengalaman belajar dan menyenangkan, tidak hanya sebagai pengalaman makan. Anak harus diberi makan di tempat yang biasa ia diberi makan.

$\checkmark$ Anak sebanyak mungkin harus makan bersama keluarga untuk menciptakan suasana yang dapat meningkatkan perkembangan nilai dan perasaan anak terhadap keluarga.

$\checkmark$ Bantu anak untuk makan.

$\checkmark$ Jangan paksa jika anak tidak mau makan. Jangan paksakan makanan masuk ke mulutnya.

$\checkmark$ Jika anak menolak untuk makan, tunggu atau tangguhkan sampai ia mau.

$\checkmark$ Jangan berikan anak terlalu banyak minum sebelum dan sewaktu ia makan.

$\checkmark$ Beri pujian kepada anak waktu ia makan.

Orangtua, ayah, anggota keluarga (kakak), pengasuh anak dapat ikut ambil bagian dalam pemberian makan aktif/responsif. 


\section{Daftar Pertanyaan dan Jawaban}

\section{Jawaban}

\section{Pertanyaan}

Apakah Menyusui menyebabkan payudara kendur?

Apakah payudara yang berukuran kecil tidak dapat menghasilkan banyak susu?

Apakah Payudara dengan puting terbenam tidak dapat menyusui?

Benarkah ASI eksklusif tidak dapat dilakukan jika ibu bekerja?

Apakah benar pemberian ASI saja cukup bagi bayi?

Benarkah Pisang dapat menyembuhkan diare pada bayi dan membersihkan usus bayi atau memebuat bayi cepat kenyang?

Benarkah Susu formula sama baiknya dengan ASI?

Apakah benar susu formula lebih baik daripada ASI untuk perkembangan otak bayi?
Payudara kendur disebabkan oleh bertambahnya usia dan kehamilan. Kegiatan menyusui sama sekali tidak mengakibatkan perubahan bentuk payudara ibu.

Payudara kecil maupun besar sama-sama dapat menghasilkan banyak susu. Yang terpenting ibu memiliki kepercayaan diri dan motivasi yang tinggi untuk menyusui bayinya. Semakin sering menyusui, payudara akan semakin banyak menghasilkan ASI.

Puting terbenam tidak berarti tidak dapat menyusui karena bayi menyusu pada payudara, bukan pada putting.

Ibu bekerja tetap dapat memberikan ASI eksklusif. Dengan cara memerah ASI sebelum berangkat kerja dan pada saat bekerja, ibu tetap dapat menjaga persediaan ASI untuk bayi yang ditinggalkan

Semua kebutuhan bayi sampai usia 6 bulan terpenuhi oleh ASI saja. Selain karena kapasitas perut bayi masih sangat kecil, bayi 0-6 bulan belum memerlukan makanan padat seperti orang dewasa yang melakukan banyak kegiatan fisik. Bayi hanya membutuhkan ASI untuk pertumbuhannya selama 6 bulan pertama sejak lahir, dan melindunginya dari berbagai penyakit.

Pisang tidak membersihkan usus bayi melainkan merusak, karena usus bayi masih belum sanggup mengolah makanan padat dalam bentuk apapun hingga usia 6 bulan.

Tidak ada cairan lain apapun yang dapat menggantikan ASI. Hanya jika diberikan ASI eksklusif saja yang membuat bayi lebih sehat.

ASI mengandung AA/DHA yang sangat penting bagi pertumbuhan otak. 


\section{Daftar Pertanyaan dan Jawaban}

\section{Pertanyaan}

Benarkah Kombinasi ASI dan susu formula adalah yang terbaik bagi bayi?

Jika ASI belum atau tidak lancar bisakah digantikan dengan pemberian susu formula?

Benarkah agar bayi tidak kuning dan tidak demam, dapat diberi makanan atau minuman lain sebelum ASI keluar?

Benarkah Jika bayi terus menangis berarti ASI-nya kurang?

Benarkah Ibu yang banyak minum susu akan menghasilkan banyak ASI?

Benarkah agar menghasilkan banyak ASI, Ibu harus banyak makan sayuran?

Benarkah jika ibu sedang sakit, bayi akan tertular melalui ASI?

Apakah ibu yang kurang vitamin tidak dapat menyusui bayinya?

\section{Jawaban}

Yang terbaik bagi bayi hingga usia 6 bulan adalah hanya menerima ASI saja.

Jika ASI belum atau tidak lancar, bayi masih memiliki daya tahan tubuh (tidak akan kelaparan) hingga $2 \times 24$ jam sejak lahir, yang dibawa sejak dalam kandungan. Meskipun ASI dirasa belum lancar atau ASI tidak keluar, Ibu harus tetap terus menyusui si bayi, karena rangsangan dari hisapan bayi akan mempercepat lancarnya produksi ASI.

Bayi yang kuning harus banyak menerima sinar matahari pagi dan lebih sering diberi ASI.

Bayi menangis belum tentu berarti lapar. Ada banyak penyebab bayi menangis, antara lain merasa tidak aman, terkejut, ngompol, dll.

Susu yang diminum ibu memberikan banyak kalsium bagi ibu, bukan menghasilkan ASI

yang lebih banyak

Banyaknya ASI yang dihasilkan tidak dipengaruhi oleh makanan atau minuman yang dikonsumsi ibu. Semakin sering bayi menyusu, semakin banyak ASI yang dihasilkan

Ketika sakit, tubuh ibu membuat zat kekebalan tubuh yang juga disalurkan kepada bayi melalui ASI sehingga bayi tidak akan ikut sakit.

Jika Ibu kurang vitamin, maka vitamin yang sampai ke bayi juga akan ikut berkurang, tetapi kegiatan menyusui tetap dapat dilakukan. Ibu hanya perlu lebih banyak mengkonsumsi makanan yang mengandung vitamin lebih tinggi, atau mengkonsumsi vitamin tambahan. 


\section{Daftar Pertanyaan dan Jawaban}

\section{Pertanyaan}

Benarkah menyusui tidak boleh dilakukan sambil berbaring?

Benarkah Bayi yang sedang sakit tidak boleh disusui?

Apakah pemberian air kepada bayi baru lahir hingga usia 6 bulan tidak akan merugikan?

Apakah ibu yang sedang sakit boleh menyusui anaknya?

\section{Jawaban}

Menyusui dapat dilakukan sambil berdiri, duduk ataupun berbaring.

Bayi yang sedang sakit harus lebih sering diberi ASI.

Pemberian air apapun kepada bayi baru baru lahir hingga usia 6 bulan hanya akan memenuhi perut bayi sehingga mengurangi ruang untuk ASI yang sangat dibutuhkan bayi. Bayi yang baru saja dilahirkan hanya boleh diberi ASI.

Seorang ibu yang sedang sakit tetap boleh menyusui bayinya, namun dengan catatan tidak sedang mengalami kondisi-kondisi seperti ibu memiliki infeksi HIV, terjangkit virus ebola, atau terkena virus herpes simplex di area payudara.

Penyakit seperti flu, batuk, diare, demam, sakit tenggorokan, atau infeksi saluran kemih bukanlah halangan untuk tetap menyusui bayi. Jangan takut ASI yang ibu miliki jadi mengandung kuman atau virus. ASI ibu menyusui tetap aman untuk diberikan pada bayi walau sedang menderita penyakit-penyakit tersebut. Bahkan ketika ibu sedang sakit, tubuh ibu secara otomatis akan membentuk antibodi terhadap penyakit yang dialami. Antibodi tersebut akan mengalir ke dalam ASI, dan ketika bayi menyusu, ia akan terlindungi dari penyakit yang ibu alami. 


\section{Daftar Pertanyaan dan Jawaban}

\section{Pertanyaan}

Bagimana jika puting susu ibu terluka, apakah pemberian ASI dapat diberhentikan?

\section{Jawaban}

Ibu sebaiknya tetap memberikan ASI walaupun terjadi lecet pada puting susu. Beberapa hal yang dapat menyebabkan puting susu ibu lecet seperti cara menyusui yang salah, adanya infeksi payudara, saluran susu tersumbat, infeksi jamur dan adanya gesekan dari mulut bayi atau pompa ASI. Ada beberapa hal yang dapat dilakukan untuk menghindari puting lecet saat menyusui seperti:

1. Hindari membersihkan bagian puting dengan sabun, karena dapat membuat kulit menjadi kering

2. Setelah selesai menyusui, peras keluar sekitar dua tetes ASI, kemudian gosokkan ke sekitar kulit puting dengan lembut

3. Biarkan puting benar-benar kering sebelum kembali berpakaian

4. Kompres dingin juga bisa membantu meredakan nyeri pada puting setelah menyusui. Caranya, bungkus es dengan selembar kain dan usapkan ke sekitar payudara dan puting. Lakukan kompres ini setiap beberapa menit sekali hingga bengkak dan nyeri berkurang

Jika puting lecet saat menyusui tidak juga membaik atau justru semakin memburuk walaupun Bunda telah melakukan cara-cara perawatan di atas, segeralah berkonsultasi dengan dokter. 


\section{MATERI MODUL}

\section{Sesi pertemuan 3. Pemantauan Pertumbuhan di Posyandu}

\section{Tujuan pembelajaran untuk keluarga ibu Baduta:}

$\checkmark$ Meningkatkan pemahaman keluarga ibu Baduta mengenai pentingnya pemantauan pertumbuhan Baduta di Posyandu

$\checkmark$ Menumbuhkan sikap positif dan dukungan keluarga dalam pemantauan pertumbuhan Baduta di Posyandu secara rutin

$\checkmark$ Mewujudkan perilaku pemantauan pertumbuhan Baduta di Posyandu yang didukung dan didampingi oleh keluarga ibu Baduta

\section{Metode penyampaian:}

1. Diskusi interaktif dengan metode komunikasi dua arah

Alokasi waktu: 15 menit

\section{Alat dan media:}

Selama diskusi, fasilitator dapat menampilkan alat dan media penyampaian informasi sebagai berikut:

1. Gambar 10. Pemantauan pertumbuhan Baduta di Posyandu

\section{Panduan diskusi:}

1. Fasilitator datang ke rumah sesuai janji dengan keluarga ibu baduta yang telah disepakai sebelumnya

2. Fasilitator menjelaskan mekanisme diskusi yang akan berlangsung, seperti bebas untuk berpendapat dan bertanya, aktif dan fokus selama berdiskusi serta bersedia meluangkan waktu selama 15 menit untuk berdiskusi secara kondusif.

3. Fasilitator memulai diskusi dengan mereview beberapa poin materi yang telah disampaikan pada pertemuan 1, selama 5 menit.

4. Fasilitator melanjutkan diskusi dengan melakukan brainstorming dengan peserta mengenai pertumbuhan Baduta dan bagaimana keluarga melakukan pemantauan pertumbuhan Baduta. Selain itu fasilitator menanyakan pemanfaatan dan akses Posyandu pada keluarga tersebut.

5. Fasilitator dapat menjelaskan peran keluarga dalam melakukan pemantauan pertumbuhan Baduta di Posyandu dengan menggunakan Gambar 10.

6. Fasilitator tetap terbuka untuk menanggapi apabila ada pertanyaan selama diskusi.

7. Fasilitator dapat menghubungkan keluarga ibu Baduta dengan Posyandu dengan cara memberikan kontak kader Posyandu atau pegawai Puskesmas.

\section{Pesan kunci:}

Dukungan dan pendampingan keluarga terutama ayah sangat penting dalam pemantauan pertumbuhan Baduta 


\section{URAIAN MATERI}

Apa peran keluarga dalam memantau pertumbuhan anak baduta di Posyandu? 
Apa peran keluarga dalam memantau pertumbuhan anak baduta di Posyandu?

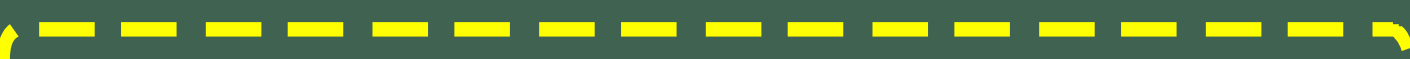

Keluarga Baduta wajib membawa anak baduta ke

Posyandu secara rutin setiap bulan. Manfaat melakukan

pemantauan pertumbuhan anak baduta di Posyandu:

$\checkmark$ Keluarga Baduta akan memperoleh informasi terkait pertumbuhan anak dan konseling terkait ASI dan MPASI secara lebih lengkap.

$\checkmark$ Keluarga Baduta dengan pengawasan dan bimbingan kader Posyandu akan memiliki kemampuan untuk membaca hasil pemantauan pertumbuhan anak pada Kartu Menuju Sehat (KMS). Dengan begitu keluarga Baduta akan mengetahui status pertumbuhan Baduta dan deteksi potens adanya stunting (di bawah garis merah) atau obesitas.

$\checkmark$ Posyandu juga memberikan pelayanan pemantauan tumbuh kembang anak untuk melihat adanya penyimpangan dalam tumbuh kembang anak. Jadi perkembangan anak dipantau melalui kemampuan gerak kasar dan gerak halus, bicara-bahasa, sosialisasi dan kemandirian anak sesuai dengan pertambahan usia. Pemantauan tersebut akan membantu dalam medeteksi dan mengatasi secara cepat apabila anak terindikasi mengalami keterlambatan tumbuh kembang.

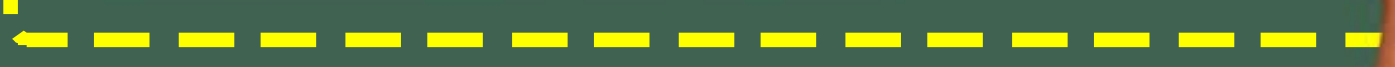
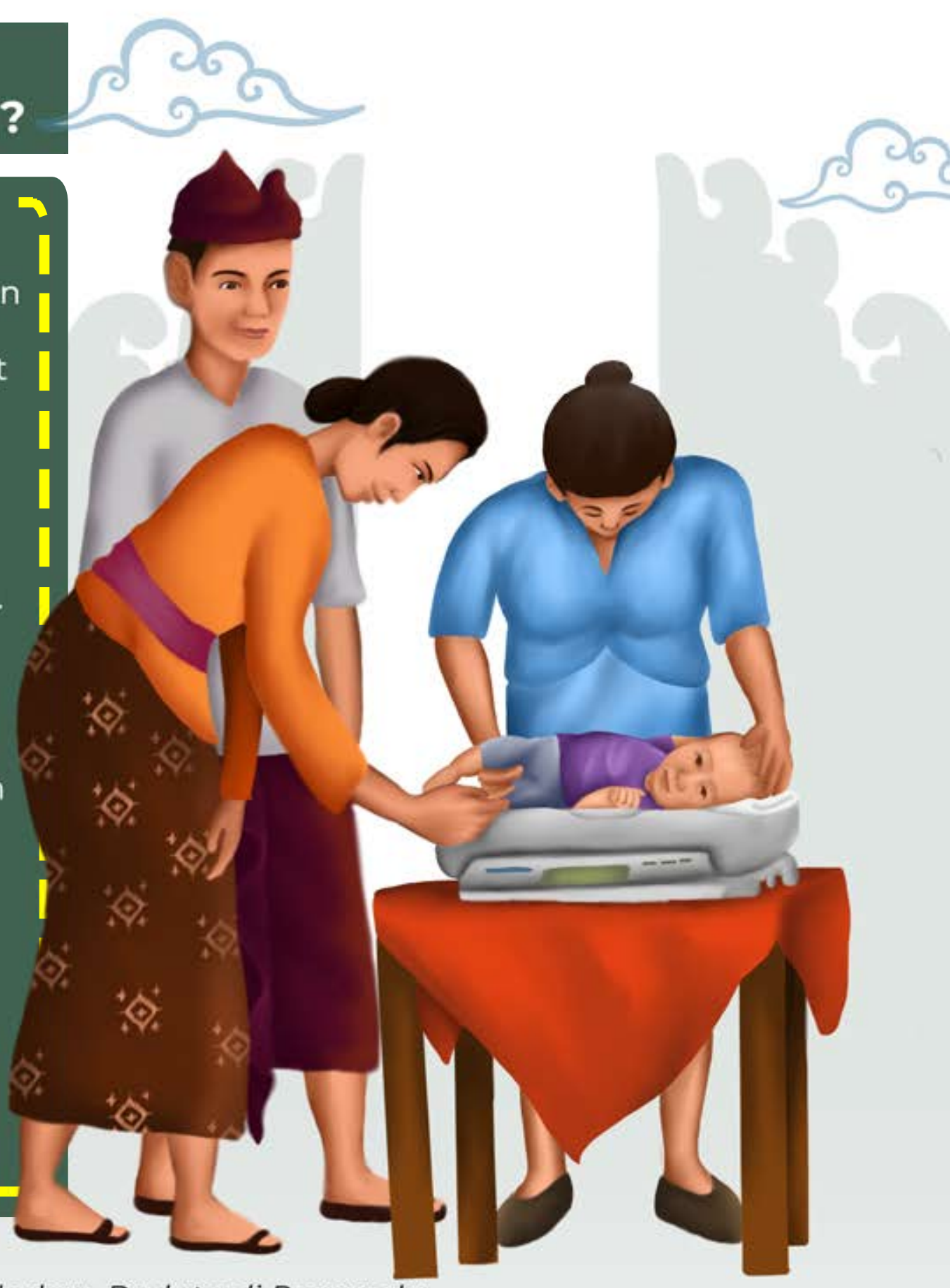

Gambar 9. Pemantauan pertumbuhan Baduta di Posyandu 


\section{Daftar Pertanyaan dan Jawaban}

\section{Pertanyaan}

Apakah apabila anak sudah mendapatkan imunisasi, jadi tidak perlu lagi datang ke Posyandu?

\section{Jawaban}

Tujuan datang ke Posyandu tidak hanya untuk imunisasi, melainkan untuk mengetahui status tumbuh kembang anak. Dengan datang ke Posyandu, keluarga baduta akan mengetahui apa saja yang dibutuhkan anaknya untuk mencapai tumbuh kembang yang optimal. 


\section{REFERENSI}

Damayanti, D., Pritasari, \& Lestari, N. T (2017). Bahan Ajar Gizi : Gizi dalam Daur Kehidupan. Jakarta: Kementerian Kesehatan Republik Indonesia.

Kemenkes (2018). Modul Kesehatan dan Gizi. Jakarta: Kementerian Kesehatan RI.

Kemenkes (2019). Pedoman Pelatihan Konseling Pemberian Makan Bayi dan Anak (PMBA). Jakarta: Kementerian Kesehatan RI.

Kemenkes (2019a) Laporan Nasional Riskesdas 2018. Jakarta.

Kemenkes (2019b) Laporan Provinsi Bali Riskesdas 2018. Jakarta.

Kemenkes (2020) Indikator Program Kesehatan Masyarakat dalam RPJMN dan Renstra Kementerian Kesehatan 2020-2024. Jakarta.

Lubis, D. et al. (2020) Potret Permasalahan Gizi di Desa Ban, Kecamatan Kubu, Kabupaten Karangasem, Bali, 2020. Denpasar.

Martin, S. L. et al. (2020) "Mixed-Methods Systematic Review of Behavioral Interventions in Low- and Middle-Income Countries to Increase Family Support for Maternal, Infant, and Young Child Nutrition during the First 1000 Days.," Current developments in nutrition, 4(6), p. nzaa085. doi: $10.1093 / \mathrm{cdn} / \mathrm{n}$ zaa085.

Walton, K. et al. (2019) "The Family Mealtime Observation Study (FaMOS): Exploring the Role of Family Functioning in the Association between Mothers' and Fathers' Food Parenting Practices and Children's Nutrition Risk.," Nutrients, $11(3)$. doi: 10.3390/nu11030630. 


\section{Protokol Kesehatan selama implementasi intervensi pendekatan keluarga pada keluarga ibu Baduta}

\section{Untuk Fasilitator}

Selalu memakai masker standar dengan benar (tidak menurunkan masker di dagu atau masker tidak menutupi hidung saat berbicara).

$\checkmark$ Fasilitator dapat menggunakan pelindung wajah (face shield), apabila tidak tersedia, fasilitator tetap harus ingat untuk tidak menyentuh wajah termasuk mata, hidung dan mulut.

$\checkmark$ Diusahakan fasilitator membawa perbekalan minum dan makan sendiri.

$\checkmark$ Diusahakan untuk tetap memakai masker atau menjauh dari tempat diskusi apabila fasilitator ingin makan atau minum bekal yang telah dibawa.

$\checkmark$ Saat proses diskusi, fasilitator harus tetap memakai masker dengan benar.

$\checkmark$ Fasilitator tetap harus membersihkan tangan sesudah menyentuh modul/alat peraga/alat-alat permainan.

$\checkmark$ Fasilitator harus mengatur jarak duduk antar peserta diskusi agar tidak terlalu dekat (minimal 1 meter)

$\checkmark$ Diusahakan memilih ruangan diskusi yang tidak terlalu sempit dan memiliki sirkulasi udara yang baik.

$\checkmark$ Sebisa mungkin fasilitator menghindari bersentuhan dengan peserta diskusi, seperti tidak berjabat tangan, berpelukan dan sebagainya.

$\checkmark$ Selalu melaksanakan etika batuk dan bersin dengan benar.

\section{Untuk Keluarga Ibu Baduta}

Meminta dengan sopan agar anggota keluarga ibu baduta yang ikut dalam diskusi agar membawa dan memakai masker dengan benar selama kegiatan berlangsung.

$\checkmark$ Memberitahu peserta diskusi dengan sopan untuk memilih tempat diskusi yang tidak terlalu sempat dan ter dapat sikulasi udara yang baik.

$\checkmark$ Meminta dengan sopan agar setiap peserta diskusi duduk dengan mengatur jarak aman (minimal 1 meter).

$\checkmark$ Memberitahukan kepada peserta diskusi untuk meminimalisir kontak fisik seperti, berjabat tangan, berpelukan dan lainnya.

$\checkmark$ Memberitahu peserta diskusi dengan sopan agar selalu mencuci tangan atau membersihkan tangan dengan hand sanitizer yang dibawa oleh fasilitator, setelah peserta diskusi memegang modul/alat peraga/ alat-alat permainan.

$\checkmark$ Memberitahu peserta diskusi dengan sopan mengenai etika batuk dan bersin selama proses diskusi ber langsung.

$\checkmark$ Memberitahukan peserta diskusi dengan sopan agar sebisa mungkin selalu menggunakan masker apabila ingin makan dan minum, atau men jauh dari tempat diskusi beberapa saat. 


\section{LAMPIRAN}




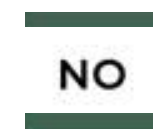

1

\section{ZAT GIZI}

Karbohidrat

Protein

\section{SUMBER BAHAN PANGAN}

Beras, jagung, umbi-umbian (ubi jalar, singkong), kentang, keladi dll

\section{Pangan hewani:}

- Daging merah, daging ayam susu, telur, ikan, udang atau pangan hewani laut lainnya Pangan nabati

- Tempe, tahu

\section{FUNGSI}

- Sebagai sumber energi utama

- Cadangan energi dalam otot dan hati

- Memperlancar pencernaan

- Sebagai pemanis alami

- Membentuk dan memperbaiki sel, serta jaringan tubuh yang rusak

- Membantu meningkatkan system kekebalan tubuh

- Membuat enzim yang memfasilitasi reaksi biokimia (mengikat hemoglobin, serta mengangkut oksigen melalui darah)

- Sebagai cadangan dan sumber energi tubuh

- Pelindung tubuh dari suhu rendah (dingin)

- Pelarut vitamin A, D, E dan K

- Penghasil energi

- Penahan rasa lapar (karena adanya lemak yang memperlambat pencernaan)

- Sebagai pelindung alat tubuh vital (jantung dan lambung)

- Menjaga kesehatan mata

- Menjaga daya tahan tubuh

- Menjaga kesehatan kulit

- Sebagai antioksidan
- Sayuran berdaun hijau seperti bay

- Buah-buahan seperti melon, mangga, pepaya, semangka, dan tomat

- Umbi-umbian berwarna seperti labu kuning Pangan Hewani (Hewan)

- Susu dan produk susu, kuning telur, dan ikan

\section{- Daging, susu, ikar}

- Kelapa, kacang tanah, kedelai dll

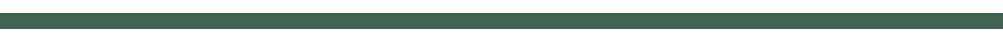




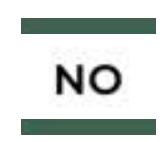

5 ZAT GIZI

Vitamin D
SUMBER BAHAN PANGAN

Pangan Hewani (Hewan)

- Ikan, telur, susu dan produk olahannya Sinar matahari

\section{Pangan Nabati (Tumbuhan)}

- Sayuran seperti kecambah dan brokoli

- Buah-buahan seperti alpukat

- Biji-bijian/kacang-kacangan

- Minyak sayur

\section{Vitamin $\mathrm{K}$}

\section{Pangan Nabati (Tumbuhan)}

- Sayuran seperti brokoli, sawi hijau, kembang kol

- Kedelai dan olahannya

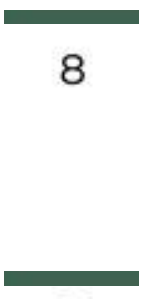

9

Vitamin C

\section{Pangan Nabati (Tumbuhan)}

- Sayuran seperti brokoli, kol dan kembang kol, paprika

- Buah-buahan seperti jeruk, jambu biji, tomat

\section{Pangan Nabati (Tumbuhan)}

- Kacang-kacangan

- Beras, gandum

Pangan Hewani (Hewan)

- Telur

\section{FUNGSI}

- Membantu metabolisme kalsium yang sangat bermanfaat dalam proses pembentukan dan menjaga kesehatan tulang.

- Menjaga dan meningkatkan daya tahan tubuh

- Sebagai antioksidan yang mencegah kerusakan sel akibat radikal bebas

- Membantu pembekuan darah saat luka

- Menjaga daya tahan tubuh

- Sebagai antioksidan

- Menjaga daya tahan tubuh

- Membantu penyerapan zat besi di dalam tubuh

- Membantu metabolisme karbohidrat menjadi energi

- Menjaga kesehatan syaraf tepi 


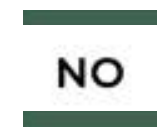

15

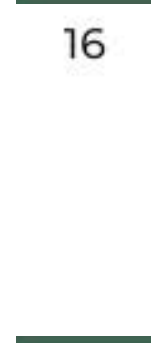

17

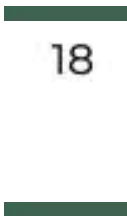

19

\section{ZAT GIZI}

Folat

Kalsium

Magnesium

Fosfor

Seng
SUMBER BAHAN PANGAN

\section{Pangan Hewani (Hewan)}

- Daging ayam, telur, hati ayam

Pangan Nabati (Tumbuhan)

- Sayuran seperti bayam, asparagus, kacang panjang dan brokoli

- Buah-buahan seperti alpukat, tomat, jeruk

- Biji-bijian dan kacang-kacangan seperti gandum

\section{Pangan Nabati (Tumbuhan)}

- Sayuran seperti brokoli, bayam, pok choi

- Kacang-kacangan, kedelai, tahu dan tempe

Pangan Hewani (Hewan)

- Susu dan produk susu, berbagai jenis ikan laut, ikan teri dan kuning telur

\section{Pangan Hewani (Hewan)}

- Ikan dan makanan laut, susu dan olahannya

Pangan Nabati (Tumbuhan)

- Sayuran hijau

- Kacang-kacangan

\section{Pangan Hewani (Hewan)}

- Daging merah, daging ayam/bebek, ikan dan telur

Pangan Hewani (Hewan)
- Daging merah, daging ayam, ikan laut, susu
Pangan Nabati (Tumbuhan)
- Kacang-kacangan

\section{FUNGSI}

- Berperan dalam pembelahan sel pada saat pembentukan janin dalam rahim

- Membantu pembentukan sel darah merah

- Membantu proses pembentukan molekul

DNA dan RNA

- Menjaga kesehatan tulang dan gigi

- Berperan dalam kerja otot

- Berperan dalam pembekuan darah

- Berperan dalam kerja otot dan sistem saraf

- Menjaga kesehatan tulang

- Menjaga kesehatan tulang dan gigi

- Menjaga keseimbangan pH tubuh

- Menjaga daya tahan tubuh

- Berperan dalam kesehatan reproduksi

- Pembentukan hormon insulin untuk

menjaga kadar gula dalam darah 


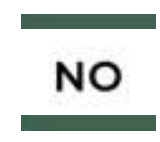

10

\section{Vitamin B2}

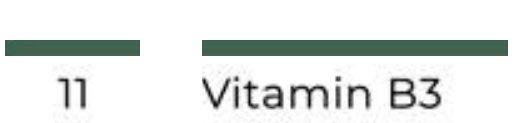

\section{Vitamin B5}

\section{Vitamin B6}

\section{SUMBER BAHAN PANGAN}

\section{Pangan Hewani (Hewan)}

- Telur, susu, daging ayam, susu

Pangan Nabati (Tumbuhan)

- Asparagus

\section{Pangan Hewani (Hewan) \\ - Ikan dan daging ayam \\ Pangan Nabati (Tumbuhan) \\ - Gandum}

\section{Pangan Hewani (Hewan)}

- Daging merah dan susu

Pangan Nabati (Tumbuhan)

- Sayuran hijau dan kacang hijau

\section{Pangan Hewani (Hewan)}

- Daging sapi/kambing dan daging ayam

Pangan Nabati (Tumbuhan)

- Buah-buahan seperti pisang

- Biji-bijian dan kacang-kacangan seperti

kacang polong dan sereal

- Kentang

\section{Pangan Hewani (Hewan)}

- Daging babi, hati sapi, hati/daging ayam, daging bebek dan ikan (terutama salmon)

\section{FUNGSI}

- Membantu pembentukan sel darah merah

- Membantu metabolisme karbohidrat menjadi energi

- Membantu metabolisme karbohidrat menjadi energi

- Membantu metabolisme zat gizi terutama lemak

- Menjaga komunikasi pada sistem saraf

- Membantu metabolisme asam lemak menjadi energi

- Membantu pembentukan sel darah merah

- Menjaga Kesehatan jantung

- Memelihara kesehatan sel saraf

- Membantu pembentukan sel darah merah

- Membantu proses pembentukan molekul DNA dan RNA 


\begin{tabular}{|c|c|c|}
\hline NO & ZAT GIZI & SUMBER BAHAN PANGAN \\
\hline 20 & Besi & $\begin{array}{l}\text { Pangan Hewani (Hewan) } \\
\text { - Hati ayam, hati sapi, kerang } \\
\text { Pangan Nabati (Tumbuhan) } \\
\text { - Sayuran berdaun hijau, kedelai dan } \\
\text { olahannya }\end{array}$ \\
\hline 21 & Iodium & $\begin{array}{l}\text { Pangan Nabati (Tumbuhan) } \\
\text { - Rumput laut } \\
\text { Pangan Hewani (Hewan) } \\
\text { - Kerang, kepala ikan } \\
\text { Garam beriodium }\end{array}$ \\
\hline 22 & Kalium & $\begin{array}{l}\text { Pangan Hewani (Hewan) } \\
\text { - Yogurt } \\
\text { Pangan Nabati (Tumbuhan) } \\
\text { - Buah-buahan seperti pisang, alpukat dan } \\
\text { kurma } \\
\text { - Ubi, kacang-kacangan }\end{array}$ \\
\hline 23 & Natrium & Garam dapur, keju, saus, kecap \\
\hline
\end{tabular}

\section{FUNGSI}

- Membantu meningkatkan fungsi sel darah merah untuk mengikat oksigen dan mengedarkannya ke seluruh tubuh

- Menjaga metabolisme tubuh

- Menjaga suhu tubuh

- Komponen penting dalam perkembangan otak

- Menjaga keseimbangan osmolaritas cairan tubuh

- Menjaga keseimbangan $\mathrm{pH}$ tubuh

Berperan dalam menjaga keseimbangan cairan tubuh dan tekanan darah 
Permasalahan gizi di Desa Ban, Kabupaten Karangasem, Provinsi Bali sudah berlangsung lama khususnya pada ibu menyusui dan baduta serta telah dilakukan berbagai upaya intervensi untuk mengatasi masalah gizi di desa ini. Mengingat luasnya dampak yang diakibatkan oleh permasalahan gizi pada ibu menyusui dan baduta, maka perlu sebuah upaya inovatif yang dapat dijadikan strategi pendekatan untuk percepatan perbaikan status gizi pada kelompok-kelompok tersebut.

Berdasarkan hal tersebut pendekatan keluarga sebagai basis dukungan perubahan perilaku dikembangkan dengan tujuan untuk meningkatan pengetahuan, menumbuhkan sikap positif dan mewujudkan perilaku yang mendukung pada pemenuhan gizi seimbang pada ibu menyusui dan baduta, sehingga dapat berdampak pada perbaikan dan peningkatan status gizi. Modul Pendidikan Kesehatan dan Pemenuhan Gizi Seimbang pada Ibu Menyusui dan Baduta, dibuat untuk menjadi pegangan petugas lapangan/fasilitator dalam menyampaikan materi yang telah direncanakan pada waktu melatih dan menemani keluarga ibu baduta. Modul ini berisikan panduan-panduan dalam pemberian materi dan permainan untuk mendukung peningkatan pengetahuan, perubahan sikap dan perilaku yang positif pada ibu menyusui dan keluarganya mengenai pemenuhan gizi seimbang untuk ibu menyususi dan anak baduta di lingkungan rumah tangganya.

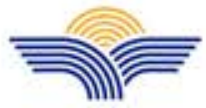

PENERBIT

PANUDUH ATMA WARAS

ISBN 978-623-97473-6-7 (PDF)

Jl. ByPass Ngurah Rai Nomor: 888 xx,

Denpasar, Bali - Indonesia

(0361) 6209990

$(+62) 82236180725$

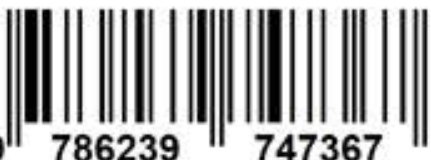

info@baswarapress.com

panuduhatmawaras@gmail.com 